\title{
Number of First Degree Relatives (Affected)
}

National Cancer Institute

\section{Source}

National Cancer Institute. Number of First Degree Relatives (Affected). NCI Thesaurus. Code C19767.

An indication of the number of direct relatives (i.e., parent, sibling, offspring) who have a particular condition. 